\title{
A Protoficção Científica no conto Demônios (1893), de Aluísio Azevedo
}

\author{
The Protoscience Fiction in Demônios (1893), by Aluísio Azevedo
}

\section{Ana Carolina Moraes da Silva ${ }^{\dagger}$ Naiara Sales Araújo ${ }^{\S^{*}}$}

Como citar esse artigo. da Silva, A.C.M.; Araújo, N.S. A Protoficção Científica no conto Demônios (1893), de Aluísio Azevedo. Revista Mosaico, v.11, n.2, p. 62 - 69, 2020.

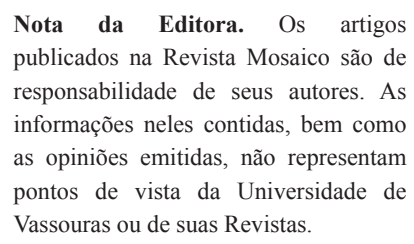
publicados na Revista Mosaico são de responsabilidade de seus autores. As informações neles contidas, bem como as opiniões emitidas, não representam pontos de vista da Universidade de Vassouras ou de suas Revistas.

\begin{abstract}
Resumo
O presente trabalho tem por objetivo analisar as características da protoficção científica brasileira no conto "Demônios" (1893), de Aluísio Azevedo, investigando como essas características estão presentes na obra, principalmente a concepção de evolução das espécies, vigente naquele século. Para tanto, como aporte teórico, levamos em consideração os conceitos de Protoficção, estudado por Roberto Causo (2003), e Ficção Científica, por Bráulio Tavares (1992). Tendo em vista a popularização do gênero Fiç̧ão Científica a partir do século XIX, com H. G. Wells, a protoficção abrange obras que utilizam elementos científicos a fantásticos antes da nomeação do gênero.
\end{abstract}

Palavras-chave: Protoficção Científica, Aluísio Azevedo, Literatura Maranhense, Fantástico.

\begin{abstract}
The present study aims to analyze the Brazilian protoscience fiction in "Demônios" (1893), by Aluísio Azevedo. Investigating how these elements are present, especially the conception of evolution of species, in force in that century. To this end, as a theoretical contribution, we take the concepts of Protoscience fiction studied by Roberto Causo (2003) and Science Fiction by Bráulio Tavares (1992). In view of the popularization of the genre Science Fiction from the 19th century with H. G. Wells, the protoscience fiction covers works that use scientific elements and fantastic before the naming of the genre.

Keywords: Protoscience Fiction, Aluísio Azevedo, Maranhense Literature, Fantasctic.
\end{abstract}

\section{Introdução}

O gênero Ficção Científica foi, durante muito tempo, associado aos avanços tecnológicos e científicos de uma nação e, por essa razão, considerado um gênero de pouco valor entre os literatos brasileiros do início do século XX. Tal fato se deve às histórias produzidas, que eram consideradas fora da agenda nacional e que tinham, para os intelectuais da época, qualidade inferior às obras literárias produzidas no mesmo período por autores consagrados no mundo.

As primeiras obras classificadas como ficção científica foram publicadas nas Pulp Magazines e eram histórias produzidas por e para os próprios membros da revista, que, por sua vez, tinham como principal objetivo causar o sense of wonder, ou seja, o efeito de despertar a admiração ou o temor dos leitores a partir da leitura de ficção científica.

De acordo com Causo (2003), na Europa, há dados de que as primeiras histórias de ficção científica surgiram no século XIX, com o advento da Revolução Industrial. Tais narrativas foram criadas como uma crítica ao profundo desenvolvimento tecnológico que surgia naquela época. A principal preocupação de seus escritores era mostrar como as novas tecnologias poderiam afetar o homem a partir do resultado de seu relacionamento com a máquina. Mary Shelley, consagrada escritora inglesa, em sua obra Frankenstein:

Afiliação das autoras:

† Graduanda do curso de Letras da Universidade Federal do Maranhão; Bolsista PIBIC -CNPQ, São Luis, MA, Brasil.

§ Dra. Literatura Comparada; Professora do Mestrado Acadêmica em Letras da Universidade Federal do Maranhão, São Luis, MA, Brasil. 
ou o moderno prometeu, de 1818, exibe o conflito entre o homem e a ciência, mostrando como a ganância do homem pode causar sua própria destruição.

Nossa intenção neste trabalho é analisar as imagens da ciência e destacar elementos da teoria darwinista sobre a evolução das espécies e, ao mesmo tempo, delinear como é traçado esse processo mediante elementos do gótico, a chamada "ciência gótica", no conto "Demônios". Nessa obra, o autor aborda conflitos internos do homem e como as consequências desse conflito levam o homem/personagem a se comportar perante a natureza.

Os textos de Aluísio Azevedo propiciam uma análise da concepção de ciência que circulava no Brasil no final do século XIX. Desse modo, sua escrita recorre a algumas construções ficcionais intimamente ligadas à teorização sobre a origem do homem e como questiona a relação do homem com a natureza. Com base nos elementos científicos e por meio da tentativa de proximidade com as questões da realidade, encontramos no texto de Aluísio Azevedo uma escrita que pode ser inserida em um grupo de narrativas que formam o que chamaremos aqui de Protoficção Científica. Esse gênero ou subgênero, estudado por Causo (2003), além de garantir mais uma possibilidade de discutir a realidade brasileira, o faz baseado nas concepções de ciência, suas dúvidas e incertezas, muitas vezes envoltas em elementos fantásticos e góticos e, por vezes, com elementos característicos da ficção científica, sem se estabelecer em uma escrita exclusivamente do gênero.

Portanto, levaremos em consideração os elementos desse texto que avaliamos relevantes para análise, com destaque para a relação Homem/Natureza e mostrar como esta se dá frente à realidade presente na obra. Teceremos, ainda, algumas reflexões sobre a construção de ciência e suas contradições no final do século XIX, bem como problematizaremos o uso da escrita de ficção científica no que diz respeito à configuração criada pelo escritor para a concepção de ciência. A relação homem e natureza será discutida de acordo com a perspectiva da criação e evolução do mundo/homem, bastante questionáveis para a época.

Considerado o pai do naturalismo brasileiro com a publicação da obra $O$ mulato, de 1881, Aluísio Azevedo foi um escritor inovador nas últimas décadas do século XIX. Apesar de ser conhecido por seus romances que representavam cenas do cotidiano brasileiro da época, seus escritos fundamentavam-se nas transformações sociais que o país padecia nesse período. Porém, obras como "Demônios" não se enquadram nessa proposta, por incluir temáticas fantásticas pouco estudadas naquele momento.

A caracterização pouco convencional da escrita azevediana, "o exagero e a inverossimilhança [...] abundantes ao longo de todo o texto" (TAVARES, 1992, p. 48), é o que se denomina uma ficção gótica. Dita por Bráulio Tavares, essa obra, que também pode ser caracterizada como "romântica, sombria e fantasmal", é passível de explicação. Além disso, nela se observa "os ambientes sombrios, a predominância de ações ocorridas à noite, as tramas misteriosas, a presença de personagens imaginativas e desconfiadas do discurso científico e o acentuado teor mórbido e sexual" (TAVARES, 1992, p.48). Ressalta-se que não era hábito do autor usar tais elementos em suas obras.

Portanto, este artigo analisa dois aspectos que caracterizam a obra em questão como pertencente ao gênero: a presença científica e a crença na mudança como crítica social. Ao analisar tais perspectivas que comprovam a "cientificidade" na obra, por intermédio da teoria darwinista, buscamos também discutir sobre o aspecto crítico-social que a temática do livro ascende, intencionando mostrar, além disso, como essa obra estava à frente de seu tempo.

\section{A natureza da Ficção Científica}

Tomando como ponto de partida a contradição entre os críticos em definir ficção científica, tem-se também a preocupação em apontar o surgimento da Ficção Científica como gênero literário. De acordo com Bráulio Tavares (1992, p. 07), em $O$ que é ficção cientifica?, "[...] está cada vez mais difícil definir com exatidão o que é a fc.", devendo-se isso ao patronato estabelecido por H. G. Wells e Júlio Verne. Verifica-se que há referências antigas quanto às narrativas fantásticas sobre viagens à Lua e a outros planetas, assim como o aparecimento de romances góticos como Frankenstein ou o Prometeu Moderno (1818), de Mary Shelley, ou a obra de Robert Louis Stevenson, O Médico e o Monstro (1886), nos quais a ficção científica se funde com a literatura fantástica.

Sabe-se que na literatura brasileira predominaram textos que manifestavam os diferentes valores sociais e morais de umaépoca. Essas características apresentavamse em produções literárias que conversavam com os princípios de uma narrativa utópica e expunham um novo conceito de sociedade, cujo principal objetivo era mostrar a ideia de futuro ou de realidade paralela. Percebe-se que o aparecimento da ciência, nesses casos, limitava-se somente a um componente apreciativo, sem resultar em choque na estrutura da história.

Contudo, segundo Tavares (1992), é possível classificar essas obras como a origem de criação que mais tarde resultou na formação, a partir da literatura fantástica, de uma escrita de ficção científica no território brasileiro. Roberto Causo (2003), tendo como alicerce o cenário da literatura "universal", roteiriza algumas obras que desde a Idade Média incluíam as características do fantástico na apresentação de sátiras, pensamentos modernos sobre cidade, realidade, povos e culturas. 
Assim, Causo (2003, p. 51) define que "[...] alguns observadores propõem que tudo que se assemelhava à ficção científica, mas produzida antes da denominação do gênero, seria definido como "protoficção científica'."

As origens de uma protoficção científica na literatura "universal", de acordo com Roberto Causo (2003), estão muito além dos textos sobre a viagem fantástica de Verne ou de Wells. A ideia de conectar-se ao futuro e ao inexplorado são vigentes em numerosas histórias mitológicas e fantásticas ao longo dos séculos. Ademais, é provável que nessas narrativas exista a chance de pensar padrões temáticos e formais que contribuíram para alguns autores desenvolverem novas histórias sem especificamente expor uma imagem de ciência:

A protoficção científica seria então um objeto ainda mais antigo. Peter Nicholls é um dos que acreditam que a ficção científica "é meramente uma continuação, sem qualquer hiato verdadeiro, de uma tradição de ficção imaginativa muito mais antiga, cujas origens estão perdidas nas brumas míticas e neblinas folclóricas da tradição oral.” (CAUSO, 2003 p. 52)

Dito isso, vale ressaltar que as obras desse período também abordavam uma outra perspectiva voltada para a problematização de questões que atingiam tanto $\mathrm{o}$ social como o político: "A maioria das obras anteriores ao século XIX tinham como tônica a descrição de utopias ou a satirização das sociedades da época." (CAUSO, 2003, p. 57)

[...] tais formas antigas da ficção científica - dispostas a fazer o leitor alcançar um mundo alternativo onde os problemas da sua sociedade possam ser vistos por uma lente aumentada - dependem de uma sólida consciência de sociedade, estado, governo, classe, nacionalidade e do jogo de opiniões.[...] talvez seja até mesmo possível estabelecer que quanto maior o sentido de nacionalidade, maiores as chances de haver alguma forma de proto fc sendo produzida em um país, de modo relativamente autônoma com respeito aos aspectos científicos e tecnológicos (CAUSO, 2003, p. 57).

Temos, então, esse elemento característico do gênero, que Roberto Causo esclarece no capítulo I de Ficção cientifica, fantasia e horror no Brasil, a desconstrução de que a Literatura de protoficção científica era voltada unicamente para o desenvolvimento de novas tecnologias. Ela era desenvolvida também como uma forma de criação utópica de uma sociedade ou até de realização de uma sátira de cunho crítico-social:

Para que a sátira e a utopia façam sentido, é necessário que o autor pressuponha a existência de falhas no sistema social e político que ele ataca, e que essas falhas possam ser corrigidas, que o sistema possa ser transformado. Em todo o caso, tais formas antigas de ficção científica dispostas a fazer o leitor alcançar um mundo alternativo onde os problemas da sua sociedade possam ser vistos por uma lente de aumento - dependem de uma sólida consciência de sociedade, estado, governo, classe, nacionalidade e do jogo de opiniões (CAUSO, 2003, p. 59).

Fica claro que o autor de protoficção deve derivar de uma sociedade cuja consciência de patriotismo prevaleça, pois, para haver a efetividade do desenvolvimento crítico, é necessário fazer parte deste dispositivo. Assim, a literatura, do período racionalista e cientificista, tinha como objetivo criar uma maneira alternativa de entrar num mundo, com seus respectivos problemas, e tentar solucioná-los. Em outras palavras, a ficção científica, seria, então, uma busca do homem por resposta às questões existenciais por meio da criação de um cenário incomum que não poderia ser solucionado na realidade. Esse cenário científico ganhou força desde o século XIX, quando as interpretações racionais se sobrepuseram às religiosas.

Outra característica na literatura de protoficção científica é a presença de alguns elementos fantásticos como objeto em análise. Para Todorov (1987, p. 59), “[...] nem toda ficção nem todo sentido literal estão ligados ao fantástico; mas todo o fantástico está ligado à ficção e ao sentido literal.". Essa concepção definida pelo autor búlgaro implica dizer que a presença do elemento fantástico se torna necessária para a estrutura da ficção científica. Para identificar tal aspecto na narrativa, é preciso reconhecê-lo como algo não familiar. Há um equilíbrio entre o real e o não real, porém, com a presença de fenômenos inexplicáveis, é possível distinguir o que é irreal e estabelecer duas realidades.

Alicerçados nessas definições e propondo uma aproximação com a escrita de Azevedo, percebemos que o conto aborda uma temática na qual a cultura brasileira não mantinha um contato direto. Ao tratar de uma realidade que, embora pouco experimentada pela sociedade, dialoga intimamente com crença e ciência, o escritor reorienta suas concepções de gênese da vida de acordo com seu entendimento da sociedade. Queremos dizer que a realidade do final do século XIX fora idealizada com base em parâmetros que não residiam no interior da própria cultura, mas poderiam ser questionados.

O cenário apresentado no texto estudado foi construído com fundamento nas diferenças existentes em relação ao passado, no contexto em que a obra foi escrita, de preceitos tradicionais, e o presente, de base cientificista, compondo, a partir de elementos fantásticos e sob a influência científica, novas descrições e comportamentos dos personagens no mundo fantástico. Por isso, de acordo com esse ponto de vista de escrita de protoficção e outros elementos em semelhança e contato com a ciência, interessou-nos apontar a escrita de Aluísio Azevedo como um exemplo desse gênero no espaço de produção brasileira. 


\section{A presença científica na obra de Aluísio Azevedo}

Levando em consideração diferentes instâncias, não podemos classificar Aluísio Azevedo como um autor que tenha criado um plano organizado para a escrita de Ficção Científica, muito menos defini-lo como um autor desse gênero; encontramos, por assim dizer, em seus escritos elementos cuja intenção mostra uma nova realidade caracterizada dentro dos princípios definidos pelo entendimento do que seria desenvolvimento científico no Brasil no final do século XIX. O texto de Aluísio Azevedo assemelha-se à ideia de protoficção científica, justamente por "[...] apresentar elementos da FC (Ficção Científica) e de textos fantásticos em circulação no Brasil e na Europa, com ideias e noções de ciência" (CAUSO, 2003, p. 51), que predominavam no território brasileiro antes da classificação do gênero.

Autores diversos foram inspirados principalmente por teorias científicas vigentes no século XIX que causavam grande polêmica por serem uma novidade que ia contra as leis da sociedade, ditas tradicionais, que seguiam os princípios da igreja. Este é o caso da teoria darwinista, na qual Darwin (2009) defendia o princípio da evolução das espécies como uma mudança das características hereditárias de uma população de seres vivos de uma geração para outra. Esse processo faz com que as populações de organismos mudem e se diversifiquem ao longo do tempo, como um processo natural.

O período do naturalismo no Brasil, contexto em que o conto "Demônios" foi escrito, inaugura o conceito de que o indivíduo é determinado pelo ambiente e pela hereditariedade, conceito atribuído pela teoria darwinista. Com esse princípio, a maneira de conceber o universo constitui um dos pilares da ciência que estava em desenvolvimento na metade do século XIX. Os naturalistas acreditavam que o indivíduo é um mero produto da hereditariedade e o seu comportamento é fruto da educação e do meio em que vive e sobre o qual age. Acreditavam, ainda, ser a seleção natural a impulsionadora da transformação das espécies, o que na época foi considerado surpreendente, de tão inovador.

Isso posto, abordaremos a seguir a obra "Demônios", num contexto em que o movimento naturalista entrava em ascensão. O conto aproxima-se da teoria da evolução, no que diz respeito à capacidade do ser humano de sofrer transformações que comprometam sua adaptação na natureza.

\section{Contextualizando a Obra}

O conto inicia-se sob a perspectiva do autor. Aluísio Azevedo coloca um ar de suspense em uma história naturalista/realista em certas partes do seu texto.
A narrativa se inicia com o personagem tendo certas alucinações que o levam a duvidar sobre a realidade daquilo. O protagonista (personagem sempre falando em 1. a pessoa) fora dormir, porém, após perceber que dormira por 12 horas seguidas, notou que o dia não amanhecia. O sol não se abria mais e o mundo estava em completa escuridão. Tudo estava fora do normal: pessoas mortas, o mundo e a natureza parados. Aparentemente, como único sobrevivente, ele mesmo. E foi quando se lembrou de sua noiva, Laura.

Decidido a sair ao encontro de sua noiva, anda pela escuridão tateando para não errar o caminho, tropeçando em cadáveres e tocando em musgos. Foi até a casa da noiva. Chegando lá, teve que entrar em todos os cômodos, onde encontrou mortos os pais da sua noiva. Depois, foi ao quarto da noiva e a encontrou sem vida, fria. Mas, depois de uns instantes, como por um milagre, a moça respira e acorda. Enfim, pelo menos a noiva, uma só pessoa no mundo, estava viva como ele.

Como não havia mais ninguém no mundo, o casal decide andar por esse "novo mundo", com a intenção de ir ao mar para morrerem juntos. Porém, coisas muito estranhas começaram a acontecer; tanto ele quanto a noiva passam por um processo de retrocesso, ao que parece: transformações foram ocorrendo no corpo dos dois, de acordo com o tempo; de mudanças físicas a mudanças mentais. Já conseguiam se comunicar por intermédio da mente e seus corpos adquiriram forças sobre-humanas até se adaptarem a forma quadrúpede, tornando-os mais como animais selvagens.

Ao final, não sentiam mais a necessidade de ingerir água ou comida, além de que o ambiente não causava nenhum desconforto e repugnância. Ambos seguem o caminho como se fizessem parte daquilo até que se unem como ramos de árvores, para, no fim, terem se transformado em nada, apenas células. "E, abraçados a princípio, soltamo-nos depois e começamos a percorrer o firmamento, girando em volta um do outro, como um casal de estrelas errantes e amorosas, que vão espaço afora em busca do ideal" (AZEVEDO, 1893, p. 83).

Com um final inesperado, o narrador revela que tudo aquilo não aconteceu, de fato. É que toda essa história aconteceu em uma noite de insônia do narrador, que, esperando o dia amanhecer, escreveu esse conto. "Ora fica aí leitor paciente, nessa dúzia de capítulos desenxabidos, o que eu [...] escrevi no meu quarto de rapaz solteiro, esperando que Sua Alteza, o Sol, se dignasse de abrir a sua audiência matutina [...]". (AZEVEDO, 1983, p. 81). Assim, o leitor se depara como um desfecho pouco trivial.

\section{A involução das espécies como elemento científico}

Os processos de involução humana, tais como 
o físico e o psicológico, presentes no conto, são os aspectos mais importantes que caracterizam essa obra como pertencente ao gênero protoficção científica, uma vez que esse elemento abre espaço para uma profunda e polêmica discussão acerca da origem das espécies. Esta temática traz um ponto de vista inverso à teoria estudada por Charles Darwin, que trata da evolução das espécies. Além disso, a narração minuciosa do processo de involução, desenvolvida a partir da percepção do personagem, proporciona também uma análise da relação homem/natureza e suas contradições no tocante à sua origem. Assim, essa obra possibilita acesso à densa contradição e ruptura ao conceito da gênese humana conservada na época em que foi produzida.

Esta análise abre espaço para outra questão pertinente ao gênero e que muitos teóricos consideram parte fundamental para a caracterização do gênero ficção científica: a crítica social. Causo (2003) acredita que, além da satirização social, a "crença na mudança" é outro elemento para a emergência de uma ficção científica. Isso implica dizer que o conto de Azevedo possivelmente traz uma perspectiva de que há outra teoria existente para a origem humana que não se limita à teoria religiosa. Esse fato mostra que o homem deveria estar apto a essas contínuas mudanças e que ambas as teorias podem se harmonizar.

Para fundamento, vê-se no início que, após deparar-se com um mundo inverso, em meio a uma cena sombria, o narrador/personagem tenta incessantemente encontrar sua amada Laura. Quando finalmente a encontra, há a percepção de que os únicos sobreviventes daquela realidade apocalíptica eram eles dois. "Ai! desgraçados de nós, minha querida Laura! De tudo que vivia à luz do sol só eles persistiam; só eles e nós dois, tristes privilegiados naquela fria e tenebrosa desorganização do mundo!" (AZEVEDO, 1893 , p. 60). O aspecto religioso descende do ponto em que as criaturas restantes nesse cenário se tratam de um homem e de uma mulher. Assim, faz-se referência aos personagens bíblicos Adão e Eva; ou seja, a narrativa ficcional científica não aborda, porém, não diverge da teoria convicta da época. As personagens de "Demônios", assim como Adão e Eva, buscam um reino de paz e amenidade e decidem trilhar um caminho para a morte em direção ao mar, onde supostamente encontrariam a paz eterna:

Ela, por fim lembrou o mar. Sairíamos juntos à procura dele, e abraçados pereceríamos no fundo das águas. Ajoelhou-se e rezou, pedindo a Deus por toda aquela humanidade que partira antes de nós; depois ergueu-se, passou-me o braço na cintura, e começamos juntos a tatear a escuridão, dispostos a cumprir o nosso derradeiro voto. (AZEVEDO, 1893, p. 57-58).

Decididos a cumprirem o voto para pôr fim a esse infortúnio, transformações incompreensíveis começam a acontecer durante o percurso, "pouco a pouco, nossos cabelos e nossos pelos se nos foram desprendendo e caindo lentamente pelo corpo abaixo." (AZEVEDO, 1893, p. 76), reduzindo-os então a seres de aspecto animalesco, o que os fazem perceber que a nova condição os torna mais à vontade do que a posição humana. O processo apreendido por Darwin (2009) destaca a teoria da Hominização, que seria um lento processo de transformação física e intelectual, no qual a espécie humana evolui, adquirindo a bipedia e a verticalidade. Sendo assim, esse seria o primeiro processo presenciado pelo personagem, a ação.

Adquiridas essas formas inversas à teoria darwinista, os personagens passam por um processo dito pelo teórico como assilvestramento (DOMINGOS, 2018). Além da perda da postura humanoide; a fala, outro aspecto de caráter humano, mostra-se desnecessária em certo ponto. Ambos, para se comunicarem, precisam unir as cabeças, fronte com fronte, como relacionamento animal. A ausência da habilidade linguística, outra etapa abordada por Darwin, deve-se ao uso da capacidade racional do homem e, consequentemente, de sua presença perante as demais espécies, o que o levou a criar a linguagem articulada e independente para viver em sociedade. De mais a mais, a degradação mental também se manifesta: "As luzes da nossa inteligência desmaiavam lentamente [...]" (AZEVEDO, 1893, p. $60)$, "a memória de uma vida passada torna-se cada vez mais longínqua." (AZEVEDO, 1893, p. 63); e, assim, são descritas como estrelas no céu que, aos poucos, se apagam para sempre.

Compreende-se que além de sofrerem com as transformações inexplicáveis, física e mental, o ambiente ao redor também passava por um processo de involução. À medida que ambos caminham em direção ao mar, o entorno parece sofrer os mesmos abalos, como que ligados à uma mesma origem. O próprio narrador salienta, o que antes era cheio de vida e agradável de se ver, agora não passa de uma atmosfera deteriorada e sem vida:

\footnotetext{
Àquela absoluta ausência do sol e do calor, formavam-se e cresciam esses monstros da treva, disformes seres úmidos e moles; tortulhos gigantescos cujas polpas esponjosas, como imensos tubérculos de tísico, nossos braços não podiam abarcar. Era horrível senti-los crescer assim fantasticamente, inchando ao lado e defronte uns dos outros como se toda a atividade molecular e toda a força agregativa e atômica que povoava a terra, os céus e as águas, viessem concentrarse neles, para neles resumir a vida inteira. Era horrível, para nós, que nada mais ouvíamos, senti-los inspirar e respirar, como animais, sorvendo gulosamente o oxigênio daquela infindável noite (AZEVEDO, 1893, p. 61).
}

O cenário no qual o ambiente "acompanha" a transformação da criatura, está descrito na teoria de Darwin (2009, p. 83), na qual ele aponta para "as condições de vida [que] serão modificadas de uma maneira essencial". Isso implica dizer que, mesmo 
passando por um processo de transição, a criatura não se habitua ao ambiente em que já estava instalada. Pelo contrário, busca um lugar totalmente diferente para acomodar-se, pois seu habitat já não lhe corresponde. Há, então, uma busca para encontrar um ambiente que corresponda a sua nova característica e adaptada a sua natureza. Gradualmente, a ciência darwinista se manifesta mais perceptivelmente, quando a involução dos personagens se torna mais intensa.

Quando, enfim, o Narrador e Laura chegam ao mar, suas características humanoides já foram perdidas, e, nesse momento, ambos começam a se unir de tal forma que assumem outra consistência. A ordem natural, agora invertida, assume o estágio primário da teoria darwinista, isto é, a matéria. O Narrador e Laura presenciam fenômenos de caráter milenar; tudo ao redor começa a se dissolver em diferentes substâncias, para reduzir-se ao "[...] primeiro matrimônio entre as duas primeiras moléculas que se encontraram e se uniram e se fecundaram, para começar a interminável cadeia da vida, desde o ar atmosférico até ao sílex, desde o eozoon até ao bípede." (AZEVEDO, 1893, p. 80). A seguir Azevedo (1893) mostra a transformação dos personagens que levam ao fim da narrativa ou, o que seria mais adequado, o começo do fim:

E sei que as nossas fibras e os nossos tecidos endureceram
a ponto de cortar a circulação dos fluidos que nos nutriam;
e que o nosso polposo âmago e a nossa medula se foi
alcalinando, até de todo se converter em grés siliciosa
e calcária; e que afinal fomos perdendo gradualmente
a natureza de matéria orgânica para assumirmos os
caracteres do mineral. (AZEVEDO, 1893, p. 79).

A temática darwiniana, abordada na narrativa, converge e, até certo ponto, junta-se à gênese humana defendida pelos princípios cristãos, cuja doutrina reconhece a origem humana a partir da criação divina. Dessa maneira, percebe-se que as duas teorias entram num diálogo: "Laura e eu, presos um ao outro pela cintura, arriscamos os primeiros passos e pusemo-nos a andar com extrema dificuldade, procurando a direção do mar, tristes e mudos, como os dois enxotados do Paraíso" (AZEVEDO, 1893, p. 60), e resulta, dessa forma, em outra característica da narrativa ficcional ou, por assim dizer, um conflito entre a filosofia predominantemente cristã de uma sociedade e o desafio da ciência acerca da veracidade dos fatos em relação à origem humana.

Para tanto, esse vínculo propõe o que acreditavam alguns autores de ficção científica, como H. G. Wells e Júlio Verne, ou seja, mostrar “ [...] um mundo alternativo onde os problemas - social ou político - possam ser vistos [...]" (CAUSO, 2003, p. 59) e que, a partir disso, poderiam ou não serem corrigidos.

\section{A busca pela Natureza}

A crítica desenvolvida a partir da teoria da evolução das espécies busca salientar como se dá o processo de relacionamento de uma espécie com a natureza. Semelhante aspecto se manifesta sutilmente no início da narrativa, e mais tarde será reconhecida como uma procura excessiva, como uma forma de salvamento perante esse evento amaldiçoado. Comparadas com o belo e aconchegante paraíso, o qual se tem prazer de apreciar, outro cenário já indicava que o narrador tinha um grande afeto pelo ambiente que o rodeava. Ao afirmar que suas únicas companhias em noites solitárias eram "[...] as minhas queridas violetas, as minhas begônias e os meus tinhorões." (AZEVEDO,1893, p. 11), que ali estavam onde podiam ser vistos da varanda; isso quer dizer, na perspectiva darwinista, que cada espécie encontra um lugar ao qual melhor se adapta, de acordo com suas condições de vida:

\footnotetext{
Meu prazer era trabalhar aí, de manhã bem cedo, depois do café, olhando tudo aquilo pelas janelas abertas defronte da minha velha e singela mesa de carvalho, bebendo pelos olhos a alma d'essa natureza inocente e namoradora, que me sorria, sem fatigar-me jamais o espírito com a sua graça ingênua e com a sua virgindade sensual (AZEVEDO, 1893, p. 12-13).
}

Quando o narrador desperta de um sono profundo, percebe que o quarto se encontra sem luz, o primeiro sinal de que algo de natureza inexplicável se sucedia. O sol que lhe oferecia "[...] os mais belos efeitos de luz." (AZEVEDO, 1893, p. 12) não existia mais, e resulta assim a incompreensão existencial do personagem. Girando em torno de si, constata que a ausência da luz não é o único elemento sem vida, mas tudo ao seu redor. $\mathrm{O}$ som que um momento atrás era preenchido com o canto dos pássaros, agora não o envolve mais. A aparente natureza inexplicável e apocalíptica da morte do mundo gera um questionamento do que teria levado a acontecer tal fenômeno, e se a única saída seria a de adequar-se a esse novo ambiente:

\footnotetext{
Que significaria isto?... que estranho cataclismo abalaria o mundo?... que teria acontecido de tão transcendente durante aquela minha ausência da vida, para que eu, à volta, viesse encontrar o som e a luz, as duas expressões mais impressionadoras do mundo físico, assim trôpegas e assim vacilantes, nem que toda a natureza envelhecesse maravilhosamente enquanto eu tinha os olhos fechados e o cérebro em repouso?!... (AZEVEDO, 1893, p. 21).
}

Inicialmente, como o único detentor de vida desse cenário, o narrador sai e, nesse momento, percebemos mais indícios de uma natureza deteriorada: "[...] o bolor principiava a formar altas camadas de uma vegetação aquosa, e que meus pés se encharcavam cada vez mais no lodo que o solo ressumbrava." (AZEVEDO, 1893, p. 38). 
A princípio, o que antes se achava belo, encontrase agora num estado lastimável, digno de repulsa. Mediante o aspecto catastrófico da natureza, o Narrador encontra Laura, desperta inexplicavelmente de um sono profundo. Era a única que "[...] não assustava naquelas trevas e não me repelia do seu leito de donzela [...]" (AZEVEDO, 1893, p. 63).

Após esse indício inicial de empatia com o ambiente, ambos creem que esse novo cenário não thes cabe, então decidem percorrer uma trajetória em direção ao mar, local onde consideram estar em um silencioso encontro com a paz eterna:

Só uma ideia, uma só, nos restava por fim: descobrir o mar, para pedir-lhe o termo daquela horrível agonia. Laura passou-me os braços em volta do pescoço, suplicando-me com o seu derradeiro pensamento que eu não a deixasse viver por muito tempo ainda. [...] E avançamos com maior coragem, na esperança de morrer (AZEVEDO, 1893, p. 63).

$\mathrm{Na}$ tentativa de encontrar um lugar de refúgio, Darwin (2009) explica que a natureza humana talvez seja diferente da selvageria na luta pela sobrevivência. $\mathrm{Na}$ transformação do homem em ser inferior, todas as características que se adequam às suas respectivas espécies, geralmente, são ditas adaptativas e permitem que os seres vivos formem certa harmonia com o ambiente, ajustando-se, assim, para a sua sobrevivência num determinado local.

No decorrer do caminho, constatam que o assombroso fenômeno estava thes invadindo, como se o mal estivesse apoderando-se de seus corpos. Como diz o próprio narrador, "[...] era a treva, bem o sentíamos! que começava, gota a gota, a cair dentro de nós." (AZEVEDO, 1893, p. 63). A percepção do personagem em relação às transformações físicas e mentais já não o afeta de maneira significativa, pois começa a perceber o referido fato como sendo algo que faz parte de sua natureza. Há, por parte dos personagens, uma "aceitação" natural das transformações que os afetam, resultando, assim, na união em um só elemento do homem com a natureza. Quando notam que já não é necessário tatearem a atmosfera que os cerca, não repelem mais o ambiente lúgubre onde se encontram, “[...] porque não havia que recear o menor choque." (AZEVEDO, 1983, p. 61); ou seja, já se sentem parte daquilo como se a natureza tivesse fundido suas reais origens e agissem por um só princípio:

Pouco a pouco foi-nos ganhando uma profunda indiferença por toda aquela lama, em cujo ventre, nós, pobres vermes penosamente nos movíamos. E deixamos que os nossos espíritos [...] num misterioso idílio em que as nossas almas se estreitavam e se confundiam. [...] O que sentíamos bem claro era que os nossos pés cada vez mais se entranhavam no lodo, e que toda aquela umidade grossa, da lama e do ar espesso, já nos não repugnava como a princípio e davanos agora, ao contrário, certa satisfação volutuosa embebernos nela, como se por todos os nossos poros a sorvêssemos para nos alimentar. (AZEVEDO, 1893, p. 60-62).

De acordo com Darwin (2009), a evolução por seleção natural se desenvolve pelo surgimento de mutações ao acaso e subsequente seleção de algumas dessas mutações pela ação do meio exterior (geralmente chamado de "ambiente"). O resultado se revela na condição de sujeitos com ditas modificações serem mais adaptados às hostilidades do ambiente e conseguirem ter mais descendentes do que as variações menos adaptadas.

A tentativa inicial de conectar-se ao novo cenário se apresenta novamente, pois assim como a degradação de seus corpos e do ambiente ao seu redor, o tempo, maior indicativo de proximidade com o mundo, mostra-se inconstante. Como consequência uma certa indiferença ao tempo percorrido, o narrador, ao lado de sua amada, Laura, já não reconhece o momento em que se encontram, pois o sol, maior relógio natural, já não mais se manifestava. Essa é outra característica destacada pelo teórico: a perspectiva temporal, no quesito transformação por seleção natural, pode decorrer de um espaço de tempo superior ao presenciado pelo homem:

\footnotetext{
Era-nos já de todo impossível reconhecer o lugar por onde andávamos, nem calcular o tempo que havia decorrido depois que estávamos juntos. Às vezes se nos afigurava que muitos e muitos anos nos separavam do último sol; outras vezes nos parecia a ambos que aquelas trevas tinham-se fechado em torno de nós apenas alguns momentos antes. [...] O que sentíamos bem claro era que os nossos pés cada vez mais se entranhavam no lodo, e que toda aquela umidade grossa, da lama e do ar espesso, já nos não repugnava como a princípio e dava-nos agora, ao contrário, certa satisfação volutuosa embeber-nos nela, como se por todos os nossos poros a sorvêssemos para nos alimentar (AZEVEDO, 1893, p. 64-65).
}

Esse cenário atemporal intensifica-se quando o narrador percebe que ao chegar ao mar este já está morto, "[...] triste mar, sem ondas e sem soluços, chumbado à terra na sua profunda imobilidade de orgulhoso monstro abatido." (AZEVEDO, 1893, p. 54), porém, já não se recorda para que o encontraram, pois sua percepção de refúgio não fazia mais sentido. Ao mar, aqui, atribui-se o significado de que há uma transição de vida, que pode levar ao bem ou ao mal. Essa transição ocorre no momento seguinte, quando ambos se unem de tal forma que os "[...] pés, num misterioso trabalho subterrâneo, continuavam a lançar pelas entranhas da terra as suas longas e insaciáveis raízes; e os dedos das nossas mãos continuavam a multiplicar-se, a crescer e a esfolhar, como galhos de uma árvore que reverdece." (AZEVEDO, 1893, p. 77). Essa cena representa a vida e a imortalidade que encontram ao final, quando eles alcançam a plenitude, também interpretada como a árvore da vida de Darwin, na qual as gerações anteriores já não fazem mais parte desse novo ambiente: 
Uma existência tranquila, doce, profundamente feliz, em que não havia desejos, nem saudades; uma vida imperturbável e surda, em que os nossos braços iam por si mesmos se estendendo preguiçosamente para o céu, a reproduzirem novos galhos donde outros rebentavam, cada vez mais copados e verdejantes. Ao passo que as nossas pernas, entrelaçadas num só caule, cresciam e engrossavam, cobertas de armaduras corticais, fazendo-se imponentes e nodosas, como os estalados troncos desses velhos gigantes das florestas primitivas. (AZEVEDO, 1893, p. 77).

Nos últimos capítulos do conto, o encontro da natureza como fuga de um lugar devastado faz-se notável novamente. Para Darwin (2009), essas modificações que as espécies sofrem são positivas independentemente do seu nível, pois essas melhorias proporcionam uma adaptação às novas condições do meio ambiente. Aos poucos, compreende-se de que modo o narrador e sua noiva encontram sua tranquilidade, que se perpetua por milênios, até desfazerem-se em éter no ar. Além disso, outro ponto de destaque é quando o narrador revela à natureza sua história, que foi fruto de uma noite de insônia. Da mesma forma como os personagens da sua história estão unidos como um só elemento da natureza, ele mostra certa reverência aos elementos que o rodeiam: "Sua Alteza, o Sol, se dignasse de abrir a sua audiência matutina com os pássaros e com as flores." (AZEVEDO, 1893, p. 81). Esse é mais um indício do tipo de conexão existente entre o personagem e a natureza, pois ela assegura as afirmações apresentadas no mundo fantástico criado na narrativa.

\section{Considerações Finais}

À guisa de conclusão, percebemos que, da análise aqui estendida, pode-se notar que no conto "Demônios" (1893), de Aluísio Azevedo, estão presentes elementos da ficção científica, bem como da fantasia, do fantástico e do gótico. Essa mistura de gêneros aliada aos conhecimentos científicos é considerada fundamental para a existência de uma narrativa caracterizada como protoficção científica. Além do mais, pôde-se constatar, ainda, que o conto se encaixa nessa categoria, por ainda fazer parte de um período no qual a denominação do gênero ficção científica ainda não tinha sido determinada, conforme a classifica Roberto Causo (2003).

Por fim, analisamos as imagens da percepção científica, descritas por meio da teorização acerca da evolução das espécies criticada pelo texto de Azevedo. As imagens dialogam com as contradições defendidas pelos preceitos vigentes na sociedade acerca da origem do homem com o universo científico no seio da modernidade brasileira. Além disso, vimos como, nesse processo de involução, o homem relaciona-se com a natureza, sintetizando uma crítica ao conflito interior experienciado pelo homem no ambiente.

\section{Referências}

AZEVEDO, Aluísio. Demônios. São Paulo: Teixeira e Irmãos, 1893.

CAUSO, Roberto de Sousa. Ficção Científica, Fantasia e Horror no Brasil: 1875 a 1950. Belo Horizonte: UFMG, 2003.

DARWIN, Charles. A origem das espécies. 6. ed. São Paulo: Hemus, 2009.

DOMINGOS, Allan Patrick de Souza. Behavior Analysis, Darwinism, and Culture: Evolution of Purificatory Practices of Inter-Nuer Slaying. Londrina, 2018. Disponível em: https://www.researchgate.net/publication/338375730 Behavior Analysis Darwinism and Culture Evolution of Purificatory Practices_of_Inter-Nuer_Slaying. Acesso em: 10 jan. 2020.

TAVARES, Bráulio. O que é Fiç̧ão Científica. São Paulo: Brasiliense, 1992.

TODOROV, Tzvetan. Introdução à literatura fantástica. São Paulo: Perspectiva, 1987 